\title{
The Effect of Nutrient Enrichment of Either the Bank or the Surface Water on Shoreline Vegetation and Decomposition
}

\author{
J. M. Sarneel, ${ }^{1,2 *}$ J. J. M. Geurts, ${ }^{3,4}$ B. Beltman, ${ }^{1}$ L. P. M. Lamers, ${ }^{3}$ \\ M. M. Nijzink, ${ }^{1}$ M. B. Soons, ${ }^{1}$ and J. T. A. Verhoeven ${ }^{1}$ \\ ${ }^{1}$ Ecology and Biodiversity Group, Department of Biology, Utrecht University, P.O. Box 80084, 3508 TB Utrecht, The Netherlands; \\ ${ }^{2}$ Department of Aquatic Ecology, Netherlands Institute of Ecology, Rijksstraatweg 6, 3631 AC Nieuwersluis, The Netherlands; \\ ${ }^{3}$ Aquatic Ecology and Environmental Biology, Institute for Water and Wetland Research, Radboud University Nijmegen, \\ Heyendaalseweg 135, 6525 AJ Nijmegen, The Netherlands; ${ }^{4} B$-WARE Research Centre, Radboud University Nijmegen,
}

Heyendaalseweg 135, 6525 AJ Nijmegen, The Netherlands

\begin{abstract}
Riparian ecosystems can harbor great diversity and provide important ecological functions such as improving water quality. The impact of eutrophication on riparian ecosystems, however, is unclear. We conducted a mesocosm experiment to study the effects of nutrient loading on riparian ecosystems. We specifically asked whether the source of nutrients in the riparian zone affects the complex interactions that occur between surface water and adjacent wetlands. We also studied litter decomposition in the wetland component of the mesocosms, because litter accumulation in fens is assumed to control succession toward floating
\end{abstract}

Received 11 February 2010; accepted 7 September 2010; published online 19 October 2010

Electronic supplementary material: The online version of this article (doi:10.1007/s10021-010-9387-5) contains supplementary material, which is available to authorized users.

Author Contributions: LL and JV contributed significantly to the study design. The experiment was conducted by JS, JG and MN. The data were analyzed by JS, who also wrote the paper, with significant inputs from all co-authors.

*Corresponding author; e-mail: j.sarneel@nioo.knaw.nl mats. Each mesocosm consisted of an upland component, referred to as the bank, and a water compartment. The bank and water compartments were planted with typical riparian zone and open water fen species prior to the addition of nitrogen $(\mathrm{N})$ and phosphorus $(\mathrm{P})$ in different combinations to either the bank or the surface water. Nutrient addition (mainly $\mathrm{P}$ ) resulted in increased plant production and higher expansion rates of plants on the bank and in the water. There were also clear interactions in plant responses between the bank and water. Only eutrophic species increased shoot densities after fertilization. Nutrient addition further resulted in higher litter production, especially on the banks, and stimulated decomposition. Both the plant responses and the litter experiment indicated that eutrophication would accelerate succession to floating mats. Such floating fen mats are not likely to have the typical species-rich combination of desirable species; however, as our results suggest that they would be dominated by a few eutrophic species.

Key words: colonization; decomposition; eutrophication; mesocosm experiment; nitrogen; phosphorus; succession; wetland. 


\section{INTRODUCTION}

The interface between upland and aquatic ecosystems, the riparian zone (hereafter referred to as bank), is an important biological and physical transition zone (Ward and others 2002). Riparian habitats can be considered a separate type of ecosystem that is characterized by a relatively high floral and faunal diversity. Riparian habitats also play a crucial role in the nutrient cycle in aquatic systems (Nilsson and Svedmark 2002; Renöfält and others 2005). Over the past decades, increased nitrogen $(\mathrm{N})$ and phosphorus $(\mathrm{P})$ inputs to terrestrial and aquatic ecosystems have resulted in drastic changes in the ecological characteristics of riparian ecosystems. Although the critical role that riparian habitats play in reducing nutrient inputs to aquatic ecosystems has been clearly documented, the effect of nutrient enrichment on the riparian zone is not well known. Neither is it known whether or not the source of nutrients to the riparian zone is important. In many instances, nutrients reach the riparian zone from adjacent uplands. In other instances, nutrients can reach the riparian zone as a result of eutrophication of adjacent aquatic habitats (Saunders and Kalff 2001).

Fens in North Western Europe, including those in the Netherlands, often have a relatively high proportion of riparian and shoreline ecosystems as they consist of a complex network of streams, ponds, and wetlands. Within this complex matrix of upland, wetland, and open water habitats, succession within open water areas results in a sequence of vegetation types that historically began with a species-rich floating fen stage. However, in The Netherlands, characteristic species that play key roles in the colonization of open water and the formation of floating vegetation mats have become very rare over the past 25 years (Verhoeven and Bobbink 2001; Lamers and others 2002; Beltman and others 2008). Moreover, as many of the existing floating mats have progressed through succession into alder forests, a large number of mat-associated species have also become very rare (Bakker and others 1994; Van Belle and others 2006). As these fen complexes are almost always embedded in agricultural landscapes, it seems likely that the loss of species is related to eutrophication either from agricultural runoff or the supply of nutrient-rich river water into fen complexes to maintain appropriate water levels. Although nature conservation agencies are concerned about the loss of species associated with floating mats, the exact cause-effect relationship behind species losses and eutrophication is not clear (Van Belle and others
2006). Moreover, in spite of numerous measures to reduce nutrient inputs in overland runoff as well as nutrient discharged into aquatic habitats, the diversity of typical fen species remains low and continues to decline in Dutch fens (Lamers and others 2002; Beltman and others 2008). As floating fens occur at the transition between water and land, they might be affected by the quality of both. Therefore, a better understanding of the interaction between enrichment of the land and the surface water and these species is required for the development of more effective restoration measures.

There is a growing body of evidence that nutrients dissolved in surface water are available for plants in the riparian zone (Schade and others 2002; Grimm and others 2003; Hultine and others 2008). Therefore, riparian fen plants that often clonally expand from the bank into the water and in this way colonize the surface water are likely to be directly affected by nutrient availability in both bank and surface water. However, the relative importance of dissolved nutrients in surface water might be small, especially when compared to the nutrient availability in mesotrophic or eutrophic peat soils. Therefore, we aimed at unraveling the effects of nutrient enrichment of either the bank or surface water on the growth of fen species and their colonization.

Nutrient availability in water and soil might also indirectly influence colonization of open water and succession towards floating mats. Eutrophication will probably affect litter accumulation, which is generally assumed to control the succession towards floating mats, for example, by providing new substratum for the roots, affecting germination, and by changing the hydrology (Van Wirdum and others 1992; Van der Putten and others 1997; Bakker and others 1997). Litter accumulation is the net result of litter production and decomposition, and both processes are affected by eutrophication. First, eutrophication will increase litter production and nutrient concentrations in litter (Shaver and Melillo 1984). Second, eutrophication will enhance decomposition as both enrichment of litter, and the surrounding substrate has been shown to increase decomposition rates (Knops and others 2002; Rejmánková and Houdková 2006). Hence, in a eutrophic situation, more litter is produced, but it may also be broken down more rapidly. However, the net effect of eutrophication on litter accumulation has seldom been assessed for freshwater wetlands (but see Rejmánková and Houdková 2006). As it is thought to fulfill an important ecological role in colonization, we also aimed at 
understanding the net effect of nutrient enrichment on litter quality and breakdown.

We conducted a mesocosm experiment to address three questions: (1) How do different combinations of nutrient additions ( $\mathrm{N}$ and/or $\mathrm{P}$ ) to the bank and surface water affect macrophyte growth in the surface water and on the bank? (2) How do these nutrient additions affect the colonization strategy of different plant species? and (3) How do they affect tissue quality and litter breakdown? We hypothesized that plants react to the availability of nutrients in their direct environment, and that a relatively high nutrient availability in the water would increase expansion to the water. The availability of nutrients could influence plant growth and colonization in two possible ways. First, if nutrient availability is low, plants produce less biomass and hence would colonize over smaller distances. Second, plants in short supply of nutrients may start to explore for better sites and would colonize over relatively larger distances per unit of biomass when compared to nutrient-rich situations (Grime 1977). As a result of the last hypothesis but not of the first, we expect a decreased shoot density per colonized distance under nutrient-poor conditions. We assume that eutrophication stimulates both litter production and decomposition and, as a null-hypothesis, hypothesize that these processes balance out (Rejmánková and Houdková 2006).

\section{Methods}

With use of a mesocosm experiment which was divided into 'terrestrial' and an 'aquatic' compartments we studied the mechanisms behind colonization of open water in eutrophic and nutrientpoor situations. Besides, we defined the effect of nutrient addition on litter accumulation, as this is thought to control the succession rate.

\section{Mesocosm Experiment}

Twenty-four polyethylene mesocosms $(1.0 \times$ $1.0 \mathrm{~m}, 30 \mathrm{~cm}$ deep) were placed at the Radboud University Nijmegen Botanical Gardens in March 2005. Each mesocosm was divided into a 'terrestrial' compartment $(40 \%$ of the surface area; hereafter referred to as bank) and a 'water' compartment $(60 \%$ of the surface area), separated from each other by a plywood board covered with antirooting cloth (Figure 1A). The terrestrial compartment was filled with unfertilized Sphagnum peat (Holland Potgrond, Poeldijk, The Netherlands) and then shaped to create a very gradually sloping bank (from 25 to $30 \mathrm{~cm}$ depth). The water compartment was filled with demineralized water and a thin sediment layer $(<5 \mathrm{~cm})$ of Sphagnum peat. During the experiment, water depth was maintained at $25 \mathrm{~cm}( \pm 5 \mathrm{~cm})$. Because the initial $\mathrm{pH}$ of the peat was low (between 4 and 5), all banks were limed with 175-g "Dolokal" $\left(75 \% \mathrm{CaCO}_{3}, 10 \% \mathrm{MgCO}_{3}\right.$, and $5 \% \mathrm{MgO}$ ) to achieve a pH between 5 and 6 before the start of the experiment. To increase and maintain an alkalinity of 1.5 meq $\mathrm{l}^{-1}$ (a common value in Dutch fens; Lamers and others 2006) in the water compartment, $20 \mathrm{~g} \mathrm{NaHCO}_{3}$ was added to the surface water in April, May, and August 2005. Mesocosms received a background dose of $\mathrm{CaPO}_{4}$ in May $2006\left(6.7 \mathrm{~kg} \mathrm{P} \mathrm{ha}^{-1}\right)$, to avoid Pdeficiency of the oligotrophic sphagnum peat after 1 year.

In April 2005, seven emergent fen species (Table 1), Calla palustris L., Equisetum fluviatile L., Glyceria maxima (Hartm.) Holmb., Juncus effusus L., Menyanthes trifoliata L., Ranunculus lingua L., and Thelypteris palustris Schott, were planted in the bank of each mesocosm. Glyceria and Juncus are typical for eutrophic shoreline vegetation (hereafter named: eutrophic macrophytes), whereas the other species are associated with mesotrophic situations

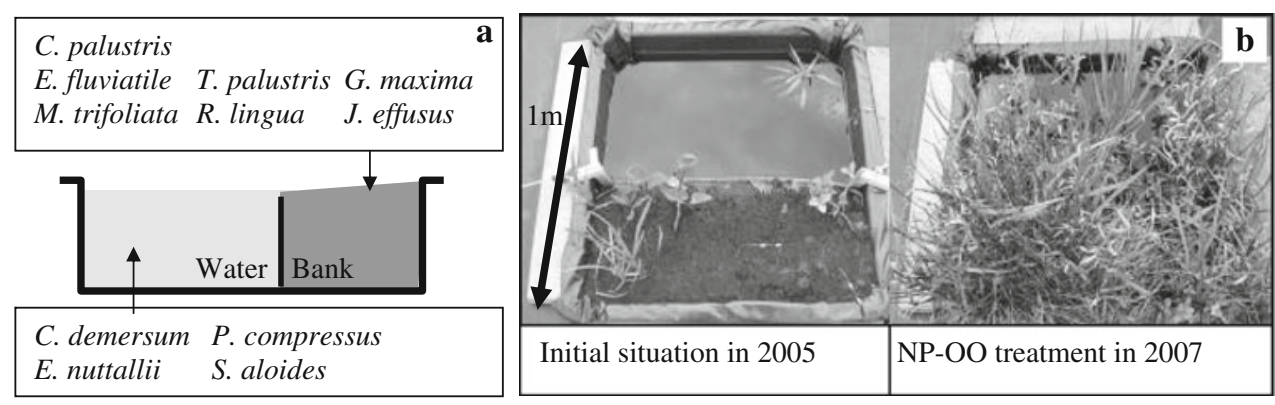

Figure 1. Experimental design of the mesocosms. A A schematic cross-section of a mesocosm in which the planted species are indicated. B Top view of the initial situation and the situation after the third growing season, showing the treatment where $\mathrm{N}$ and $\mathrm{P}$ were added only to the bank. Full species names can be found in Table 1 . 
Table 1. Yearly Measured, Non-destructive Growth and Colonization Parameters per Species

\begin{tabular}{|c|c|c|c|c|}
\hline & $\begin{array}{l}\text { Initial number } \\
\text { of plants } \\
\text { planted }\end{array}$ & $\begin{array}{l}\text { Initial fresh } \\
\text { weight (g) } \\
\text { per mesocosm }\end{array}$ & $\begin{array}{l}\text { Growth parameter } \\
\text { per compartment }\end{array}$ & Clonal growth \\
\hline \multicolumn{5}{|l|}{ Bank species } \\
\hline Calla palustris L. & 3 & $50.6 \pm 8.4$ & Number of leaves & $\begin{array}{l}\text { Distance between the two } \\
\text { most remote plants }\end{array}$ \\
\hline Equisetum fluviatile L. & 3 & $11.1 \pm 2.1$ & Number of shoots & $\begin{array}{l}\text { Distance between the two } \\
\text { most remote plants }\end{array}$ \\
\hline Glyceria maxima (Hartm.) Holmb. & 2 & $14.0 \pm 4.1$ & Number of shoots & $\begin{array}{l}\text { Distance between the two } \\
\text { most remote plants }\end{array}$ \\
\hline Juncus effusus L. & 4 & $15.8 \pm 1.6$ & Number of shoots & Tussock diameter \\
\hline Menyanthes trifoliata L. & 3 & $28.0 \pm 5.3$ & Number of leaves & $\begin{array}{l}\text { Distance between the two } \\
\text { most remote plants }\end{array}$ \\
\hline Ranunculus lingua $\mathrm{L}$. & 2 & $23.0 \pm 11.7$ & Number of leaflets & $\begin{array}{l}\text { Distance between the two } \\
\text { most remote plants }\end{array}$ \\
\hline Thelypteris palustris Schott & 2 & $15.7 \pm 4.1$ & Number of leaves & $\begin{array}{l}\text { Distance between the two } \\
\text { most remote plants }\end{array}$ \\
\hline \multicolumn{5}{|l|}{ Aquatic species } \\
\hline Ceratophyllum demersum $\mathrm{L}$. & 10 & $21.9 \pm 1.1$ & Number of shoots & Total stem length \\
\hline $\begin{array}{l}\text { Elodea nuttallii (Planch.) } \\
\text { H. St. John }\end{array}$ & 10 & $4.0 \pm 0.2$ & Number of shoots & Total stem length \\
\hline Potamogeton compressus L. & 2 & $2.7 \pm 0.9$ & Number of shoots & Total shoot length \\
\hline Stratiotes aloides L. & 3 & $55.1 \pm 9.9$ & Number of rosettes & $\begin{array}{l}\text { Summed rosette } \\
\text { diameter }\end{array}$ \\
\hline
\end{tabular}

and the formation of floating mats (mesotrophic macrophytes). Four aquatic species were planted in the water compartment. Ceratophyllum demersum L. and Elodea nuttallii (Planch.) H. St. John are typical of eutrophic conditions, whereas Potamogeton compressus L. and Stratiotes aloides L. are associated with mesotrophic conditions. All species were collected in Dutch fens. Other species that colonized the mesocosms were weeded.

The 24 mesocosms were randomly allocated to six fertilization treatments, each with four replicates. The treatments, reflecting commonly occurring situations in fens, were: (1) NP-NP; N and P added to both the bank and the water compartment, (2) OO-NP; N and P added only to the bank, (3) NP-OO; $\mathrm{N}$ and $\mathrm{P}$ added only to the water, (4) NO-OO; only N added only to the water, (5) OPOO; only P added only to the water and (6) OOoO; no fertilization. The first two letters of the codes indicate the nutrients added to the water and the latter two the nutrients added to the bank.

In the NP-NP and OO-NP treatments, the bank was fertilized each year in May with $\mathrm{CaPO}_{4}$ (70 kg P ha $\left.{ }^{-1} \mathrm{y}^{-1}\right)$ and $\mathrm{NH}_{4} \mathrm{NO}_{3},\left(600 \mathrm{~kg} \mathrm{~N} \mathrm{ha}^{-1} \mathrm{y}^{-1}\right.$; half in the form of slow release Osmocote granules). These applications reflect very heavily fertilized agricultural areas (Schils and Snijders 2004). N $\left(\mathrm{NH}_{4} \mathrm{NO}_{3}\right)$ and $\mathrm{P}\left(\mathrm{NaH}_{2} \mathrm{PO}_{4}\right)$ addition to the water occurred in three-weekly doses, resulting in a yearly dose of $6 \mathrm{~kg} \mathrm{P} \mathrm{ha}^{-1}$ and $25 \mathrm{~kg} \mathrm{~N}^{-1}$, leading to the concentrations that occur in polluted surface waters in fens (Lamers and others 2006).

Seasonally, the water compartment was sampled by collecting $100 \mathrm{ml}$ of water in iodated polyethylene bottles. Simultaneously, pore water in the bank compartment was sampled at three distances from the water line $(10,20$, and $30 \mathrm{~cm})$, using a 10-cm long Rhizon soil moisture sampler (Eijkelkamp Agrisearch Equipment, Giesbeek, The Netherlands) and vacuum glass infusion bottles $(30 \mathrm{ml})$.

At the end of each growing season, plant cover of the emergent macrophytes was estimated for both bank and water compartments separately. Nondestructive parameters of shoot growth and clonal expansion were measured (Table 1). In September 2007, at the end of the third growing season, all aquatic species and the aboveground biomass of the emergent macrophytes were harvested and sorted into dead (brown) and living material (green) per species and per compartment. The samples were dried for $24 \mathrm{~h}$ at $70{ }^{\circ} \mathrm{C}$, weighed, and ground to determine $\mathrm{N}$ and $\mathrm{P}$ concentrations (see below).

\section{Decomposition}

To estimate net litter accumulation in both enriched and poor situations, a litter bag decomposition experiment was conducted with litter from 
Glyceria that was harvested in September 2006. Glyceria was chosen because this species produced a substantial amount of litter in the majority of the mesocosms. Litter from fertilized banks (enriched litter) and non-fertilized banks (poor litter) was kept separate. The litter was air dried, cut to smaller pieces $(5 \mathrm{~cm})$, and put in $10 \times 10 \mathrm{~cm}$ mesh bags $(0.3 \mathrm{~mm})$. In early November 2006, these were inserted vertically to a depth of 5-7 cm in the bank compartment of the NP-NP and OO-OO treatments. Bags were retrieved after 3, 6, 9, and 10 months. For the poor litter, harvesting took place after 6 and 10 months due to limited quantity of litter type. Retrieved litter was carefully cleaned and dry weight, $\mathrm{N}$ and $\mathrm{P}$ concentrations were determined.

\section{Chemical Analysis}

The $\mathrm{pH}$ of water samples was measured directly using a combined $\mathrm{pH}$ electrode with an $\mathrm{Ag} / \mathrm{AgCl}$ internal reference (Orion Research, Beverly, California) and a TIM800 pH meter. Subsequently, surface water samples were filtered through glass microfiber filters (type GF/C, Whatman, Brentford, UK) followed by the addition of citric acid $\left(0.6 \mathrm{mmol} \mathrm{l}^{-1}\right)$ to prevent metal precipitation. The samples were stored in iodated polyethylene bottles at $-20^{\circ} \mathrm{C}$ until further analysis. Concentrations of $\mathrm{NO}_{3}{ }^{-}$and $\mathrm{NH}_{4}{ }^{+}$in the water samples were measured colorimetrically with an Auto Analyzer-3 system (Bran and Luebbe, Norderstedt, Germany), using hydrazine sulfate (Kamphake and others 1967) and salicylate (Grasshoff and Johannsen 1972), respectively. Total $P$ was measured using an ICP Spectrometer (IRIS Intrepid II, Thermo Electron Corporation, Franklin, Massachusetts). A homogenized portion of 150-mg dried plant material was used to determine $\mathrm{N}$ and $\mathrm{P}$ concentrations in Glyceria using a salicylic acid thiosulfate modification of the Kjeldahl digestion (Bremner and Mulvaney 1982). $\mathrm{N}$ and $\mathrm{P}$ concentrations were determined colorimetrically on a continuous flow analyzer (SA-40, Skalar Analytical, Breda, the Netherlands).

\section{Data Analysis}

A repeated measure ANOVA was carried out to test the effect of treatment (between-subjects factor) on the increase of emergent macrophyte cover in the water compartment over time (within-subjects factor). For all other growth and colonization parameters (nutrient concentrations, total biomass, species richness, diversity, evenness, colonization parameters; see Table 1, nutrient concentrations in the plant and nutrient use efficiencies), differences between treatments were tested with a one-way ANOVA. Dunnett's post hoc tests were preformed afterward, comparing all treatments to the control (OO-OO) treatment. The treatment effects were tested separately for the bank and the water compartment.

To test differences between nutrient concentrations in the surface water and pore water samples between the treatments, we used the overall mean of the different sampling dates per mesocosm, log $(x+1)$ transformed to improve homogeneity of variance. Pore water concentrations from different positions on the bank were averaged, as they were significantly indifferent. Cover data and total species richness of the last growing season were used to calculate Simpson's diversity index $(D)$ and evenness $(E)$ (Appendix 2 in Supplemental Materials for formulas; Begon and others 1996). The four aquatic species were considered one functional group and hence their biomasses were summed per mesocosm. N and P use efficiency (NUE and PUE, respectively) of Glyceria were calculated under the assumption of steady state conditions as the yearly aboveground litter production (g) divided by the total nutrient loss $(\mathrm{mg})$ via plant litter (Vitousek 1982). All statistical analyses were carried out in SPSS 16.0.

\section{RESUlts}

\section{Mesocosm: Nutrients}

Overall, the nutrient additions were significantly reflected in the nutrient concentrations in the bank pore water and surface water (Appendix 1 in Supplemental Material). Besides, P concentration in the water compartment increased by fertilization of the bank (Appendix 1 in Supplemental Material). Nutrient addition to the water compartment did not significantly increase concentrations in bank pore water. The $\mathrm{pH}$ of bank pore water ranged from 5.4 to 5.8 and the $\mathrm{pH}$ of the water compartment from 6.7 in the treatments where the bank was fertilized to 7.3 in the other treatments (one way ANOVA $P<0.001$; Appendix 2 in Supplemental Materials).

\section{Mesocosm: Vegetation Development}

During the first year, ramets of Calla and Menyanthes expanded from the bank to the open water compartment. Glyceria, Equisetum, and Ranunculus ramets grew into the water compartment after the second growing season. Thelypteris ramets did not appear in the water compartment and most plants 


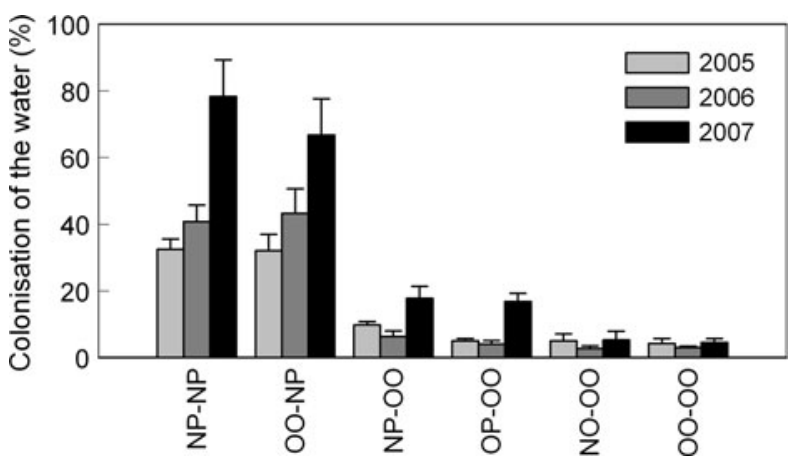

Figure 2. Mean total cover of the emergent macrophytes in the water compartment in the different treatments.

died during the study. The percent cover of macrophytes appearing in the water compartment increased significantly over time (Repeated measures ANOVA; $P<0.001$; Figure 2), and the highest values occurred in mesocoms where nutrients were added to the bank (Dunnet's post hoc $P>0.001$ ). Whereas the mesotrophic species almost doubled their cover of the water over the last two growing seasons (for example, NP-NP treatment; $70 \%$ increase), the increase of Glyceria cover was much higher $(1400 \%)$. After three growing seasons, both compartments of the NP-NP and OO-NP treatments were completely covered with emergent macrophytes (Figures 1B, 2). Menyanthes had the highest cover in the water compartments $(20-60 \%)$. In the same treatment, Glyceria and Juncus dominated the bank compartment (together covering $30-70 \%$ ). In the other treatments cover ranged between $20-30 \%$ in the bank and $5-20 \%$ in the water compartment (Figure 2). Besides, the water compartments of the NP-OO, OP-OO, and NO-OO, treatments were (partly) covered with floating filamentous algae (data not shown).

Due to the expansion of the bank macrophytes into the water compartment in the treatments with nutrient addition to the bank, the number of species and the Simpson's diversity index significantly increased in the water compartment (One-way ANOVA, $P<0.001$; Appendix 2 in Supplemental Materials). There was a trend that the evenness was lower in the treatment where nutrients were added to the bank (one-way ANOVA P $=0.078$; Appendix 2 in Supplemental Materials), indicating dominance (by Juncus and Glyceria).

The differences in cover percentages were reflected in differences in the total aboveground biomass (Figure 3). Both eutrophic and mesotrophic macrophytes produced significantly more biomass on the bank and in the water compartment after NP addition to the bank (Figure 3; Table 2).

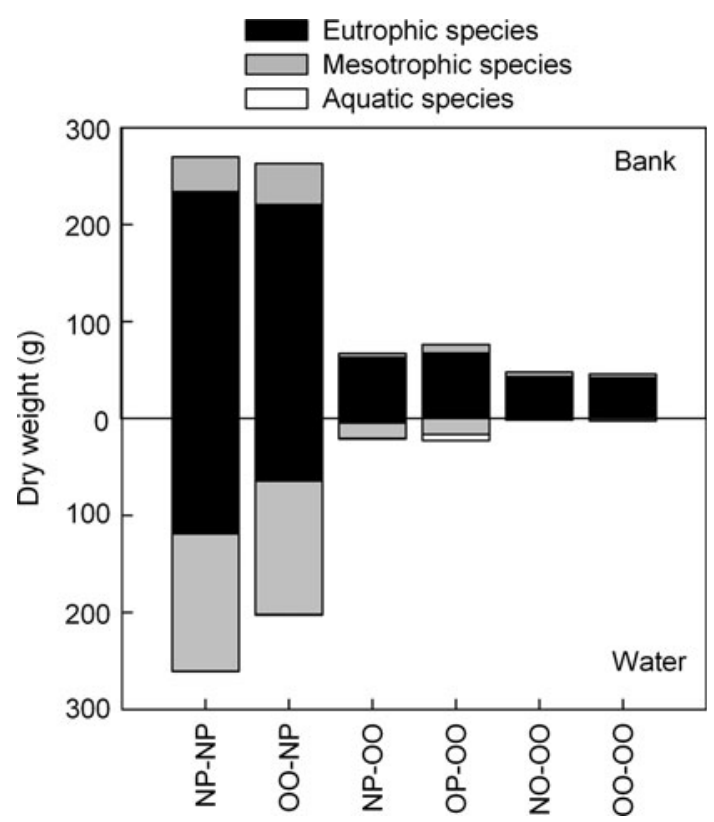

Figure 3. Total biomass (g dry weight) of aquatic species, eutrophic and mesotrophic emergent macrophytes on the bank $\left(0.4 \mathrm{~m}^{2}\right)$ and in the surface water $\left(0.6 \mathrm{~m}^{2}\right)$ in the treatments after the 3rd growing season.

Aquatic species almost disappeared and the emergent macrophytes growing from the bank almost entirely filled the water compartments (Figure 2). In the treatments where $\mathrm{P}$ was added only to the surface water, total biomass increased both on the bank and in the water. On the bank, only eutrophic species (mainly Juncus) increased in biomass, whereas in the water compartment, the mesotrophic emergent macrophytes increased (Figure 3; Table 2). Aquatic species (mainly Elodea and Ceratophyllum) had the highest biomass in the OP-OO treatment (Figure 3; Table 2). Whenever $\mathrm{P}$ was available in the water compartment, between 20 and $50 \%$ of the total mesocosm biomass was located in the water compartment.

The measures of clonal expansion were lower in the water compartment than on the bank (Table 1), and the highest values were associated with fertilization of the bank compartment, except for Ranunculus (Figure 4A). Nutrient additions to the water only had an effect on rhizome growth of Menyanthes in the OP-OO treatment $(P=0.05$; Figure 4A). The shoot densities of Juncus and Glyceria were significantly higher when nutrients were added to the bank in the NP-NP $(P>0.006$ and $0.08)$ and OO-NP $(P>0.02$ and 0.02$)$ treatments. Nutrient enrichment of the water did not result in differences in growth structure for any species growing on the bank (Figure 4B). 
Table 2. $\quad P$ and $F$ Values of the One-way ANOVAs and Dunnett's post-hoc test on Harvested Biomasses

\begin{tabular}{llllllll}
\hline & NP-NP & OO-NP & NP-OO & OP-OO & NO-OO & $F$ value & $P$ value \\
\hline Bank & & & & & & & \\
$\quad$ Eutrophic species & $<0.01$ & $<0.01$ & n.s. & 0.08 & n.s. & 34.7 & $<0.01$ \\
Mesotrophic species & $<0.01$ & $<0.01$ & n.s. & n.s. & n.s. & 12.1 & $<0.01$ \\
$\quad$ Total & $<0.01$ & $<0.01$ & 0.12 & 0.03 & n.s. & 45.8 & $<0.01$ \\
Water & & & & & & & \\
Eutrophic species & $<0.01$ & $<0.01$ & n.s. & n.s. & n.s. & 26.2 & $<0.01$ \\
Mesotrophic species & $<0.01$ & $<0.01$ & $<0.01$ & $<0.01$ & n.s. & 56.3 & $<0.01$ \\
Aquatic species & n.s. & n.s. & n.s. & $<0.01$ & n.s. & 11.4 & $<0.01$ \\
Total & $<0.01$ & $<0.01$ & $<0.01$ & $<0.01$ & n.s. & 61.7 & $<0.01$ \\
\hline
\end{tabular}

\section{Litter Accumulation}

As biomass production was stimulated by enrichment of the bank (Figure 3), litter production by Glyceria was much higher in the enriched treatments, both in the water and on the bank (Table 3). Nutrient concentration in litter increased significantly in the NP-NP and OO-NP treatments (Table 3) as a result of increased nutrient concentrations in living tissue (significant for P; Table 3). NUE and PUE were significantly lower on the banks of those treatments (Table 3). Nutrient addition to the surface water did not affect the litter quality significantly.

Litter quality did not affect decomposition rates (Figure 5). However, both litter types decomposed significantly faster in the NP-NP treatment, indicating that there was a strong influence of site conditions on decomposition (two-way ANOVA; $P=0.001)$. The calculated net effect of increased litter production and increased decomposition was an increase in the amount of standing litter after 10 months in the NP-NP treatment for Glyceria litter (Table 4). During decomposition, both $\mathrm{N}$ and $\mathrm{P}$ concentrations decreased in the litter in the NP-NP treatment, whereas concentrations increased in the OO-OO treatment. As a result, large amounts of nutrients could be mobilized during decomposition in the NP-NP treatment, whereas in the OO-OO treatment a P immobilization occurred (Table 4).

\section{Discussion}

Although the critical role that riparian habitats play in reducing nutrient inputs to aquatic ecosystems has been clearly documented, the effect of nutrient enrichment on the riparian zone is not well known. Therefore, we evaluated the importance of nutrient enrichment of water and bank for (1) the growth of shoreline species, (2) their colonization strategy, and (3) the litter quality and accumulation in shorelines of fens.

\section{Effects on Plant Growth}

The results clearly show that nutrient levels in the surface water and in the bank both affected the growth and clonal expansion of the plants. Species planted in the bank compartment expanded into and became dominant in the water compartment, especially when nutrients were added to the bank compartment. We only found that the addition of nutrients in the water compartment affected plants when nutrient concentrations in the banks were low. Other studies that report effects of nutrient concentrations of surface water on riparian vegetation were also conducted in relatively nutrientpoor systems (Schade and others 2005; Hultine and others 2008; Banach and others 2009; Geurts and others 2009) and enrichment of the bank could obscure the effects of water quality (Geurts and others 2009). Nutrients in surface waters are hypothesized to increase the biomass of the plants on the bank via two mechanisms (Schade and others 2005; Hultine and others 2008). First, by plastically adjusting their root architecture to the bank zone closer to the surface water (Robinson 1994; Hodge 2004), plants can directly take up nutrients originating from the enriched surface water (Schade and others 2005; Hultine and others 2008). Second, Schade and others (2002) found indications that enrichment of the surface water stimulates mineralization of organic compounds in the whole infiltration zone, thus increasing nutrient availability for plant growth in a wider zone compared to the previous mechanism. Both mechanisms could have occurred in our mesocosm experiment.

\section{Effects on Colonization}

With nutrient addition, macrophyte cover increased in the water compartment as the plants expanded through increased clonal growth. Comparing plant performance of species characteristic 

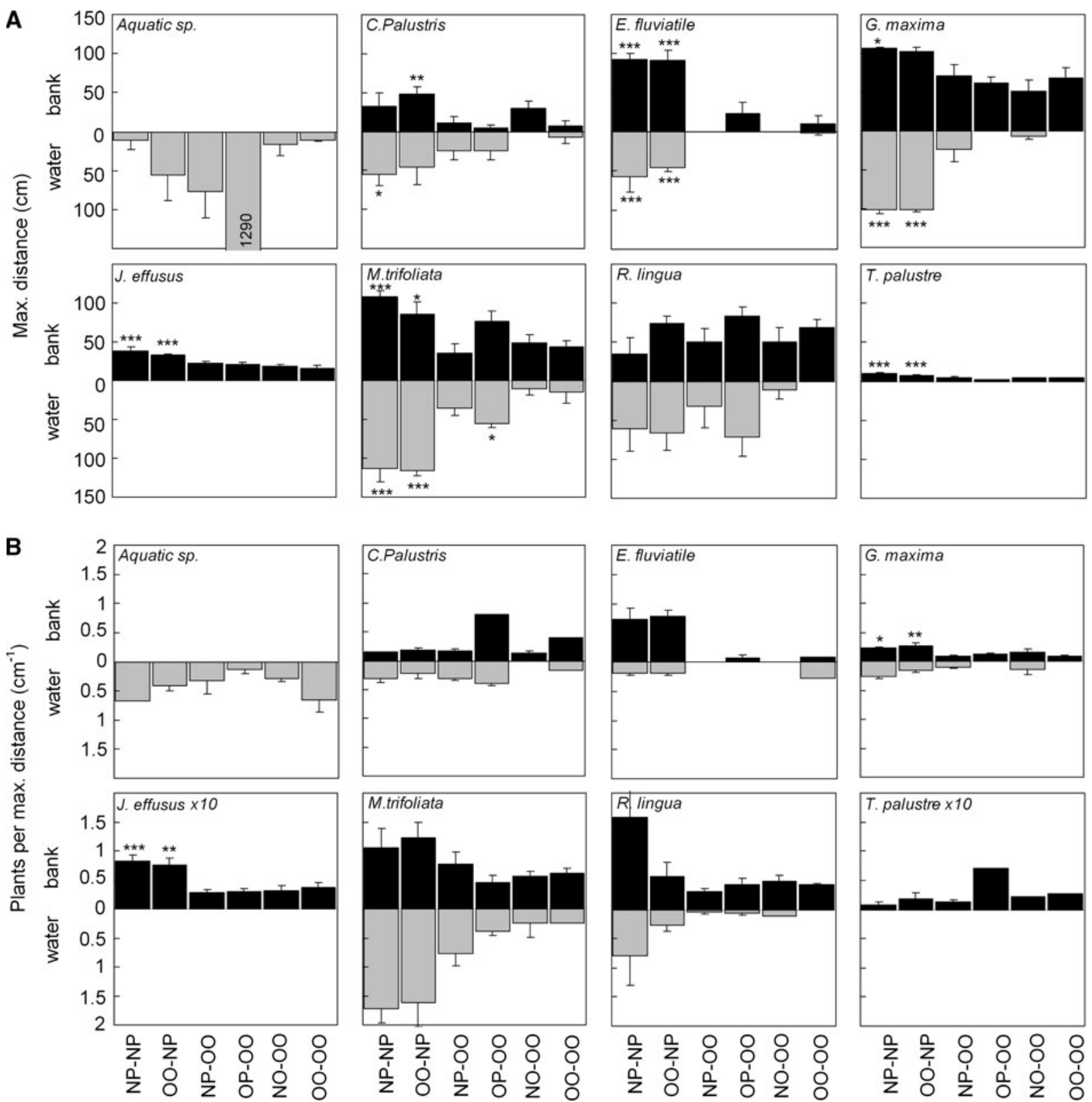

Figure 4. A Mean colonization distance (Table 1) in the water compartment and on the bank of each species separately $( \pm \mathrm{SE})$. B Number of plants or shoots per cm colonized distance $( \pm \mathrm{SE})$. ${ }^{*} P<0.10, * * P<0.05$, ${ }^{* * *} P<0.01$. Full species names can be found in Table 1 . The number of replicates was too low to perform post hoc tests for the water compartments.

of eutrophic and mesotrophic conditions provided insight into the eventual effects of increased nutrient availability on species composition of floating mats of vegetation during succession. Eutrophic species put more biomass into shoot production compared to mesotrophic species, eventually resulting in the exclusion of mesotrophic species due their better competitive ability (Grime 1977). Nutrient enrichment commonly induces a shift from nutrient competition towards light competition (Grime 1977; Portielje and Roijackers 1995; Smith and Smith 1998; Macek and Rejmánková 2007), in terrestrial as well in aquatic systems (Grimm and others 2003). This trend already became visible within our 3-year study, suggesting even stronger effects in the longer term. As vegetation cover approached $100 \%$ after the third year, competition will become much more important than it was during our experiment. $\mathrm{Al}$ though the mesotrophic species Menyanthes, which 
Table 3. Biomass, Nutrient Concentrations, NUE and PUE of Glyceria

\begin{tabular}{|c|c|c|c|c|c|c|c|c|}
\hline & NP-NP & OO-NP & $\mathrm{NP}-\mathrm{OO}$ & $\mathrm{OP}-\mathrm{OO}$ & $\mathrm{NO}-\mathrm{OO}$ & $\mathrm{OO}-\mathrm{OO}$ & $F$ value & $P$ value \\
\hline \multicolumn{9}{|l|}{ Bank } \\
\hline Biomass living (g) & 20.36 & 18.74 & 1.50 & 0.88 & 0.947 & 0.87 & 2.30 & 0.089 \\
\hline Biomass dead (g) & $44.58 * *$ & $49.09 * * *$ & 2.93 & 2.83 & 2.59 & 2.15 & 7.03 & $<0.01$ \\
\hline $\mathrm{N}$ in living tissue $\left(\mathrm{mg} \mathrm{g}^{-1}\right)$ & 23.23 & 22.37 & 14.72 & 15.41 & 17.29 & 17.59 & 4.12 & 0.012 \\
\hline $\mathrm{N}$ in dead tissue $\left(\mathrm{mg} \mathrm{g}^{-1}\right)$ & $18.85 * * *$ & $17.19 * * *$ & 8.01 & 9.93 & 10.35 & 9.85 & 16.05 & $<0.01$ \\
\hline NUE $\left(g^{-1}\right)$ & $54.7 * * *$ & $58.5^{* * *}$ & 126.5 & 104.0 & 98.8 & 103.9 & 12.04 & $<0.01$ \\
\hline $\mathrm{P}$ in living tissue $\left(\mathrm{mg} \mathrm{g}^{-1}\right)$ & $2.57 * * *$ & $2.02 * * *$ & 0.21 & 0.27 & 0.27 & 0.26 & 20.37 & $<0.01$ \\
\hline $\mathrm{P}$ in dead tissue $\left(\mathrm{mg} \mathrm{g}^{-1}\right)$ & $2.03 * * *$ & $1.56 * * *$ & 0.08 & 0.13 & 0.10 & 0.12 & 22.31 & $<0.01$ \\
\hline PUE $\left(g^{-1}\right)$ & $544 * * *$ & $670 * * *$ & 12471 & 8255 & 10738 & 10117 & 14.14 & $<0.01$ \\
\hline \multicolumn{9}{|l|}{ Water } \\
\hline Biomass living $(\mathrm{g})$ & $26.91 * *$ & 16.19 & 3.03 & 0.0 & 0.17 & 0.0 & 3.72 & 0.017 \\
\hline Biomass dead (g) & $91.92 * * *$ & $60.50 * *$ & 1.71 & 0.0 & 0.29 & 0.0 & 9.88 & $<0.01$ \\
\hline $\mathrm{N}$ in living tissue $\left(\mathrm{mg} \mathrm{g}^{-1}\right)$ & 14.15 & 12.42 & 12.21 & & 16.88 & & 0.36 & n.s. \\
\hline $\mathrm{N}$ in dead tissue $\left(\mathrm{mg} \mathrm{g}^{-1}\right)$ & 13.32 & 10.45 & 7.02 & & 9.19 & & 3.80 & 0.066 \\
\hline $\operatorname{NUE}\left(g^{-1}\right)$ & 77.95 & 96.70 & 142.53 & & 108.78 & & 11.01 & $<0.01$ \\
\hline $\mathrm{P}$ in living tissue $\left(\mathrm{mg} \mathrm{g}^{-1}\right)$ & 1.60 & 1.38 & 0.15 & & 0.14 & & 4.37 & 0.05 \\
\hline $\mathrm{P}$ in dead tissue $\left(\mathrm{mg} \mathrm{g}^{-1}\right)$ & 1.11 & 0.96 & 0.08 & & 0.13 & & 6.14 & 0.023 \\
\hline PUE $\left(g^{-1}\right)$ & 987 & 1121 & 11932 & & 7661 & & 655.0 & $<0.01$ \\
\hline
\end{tabular}

Notes: $F$ and $P$ values were obtained from one-way ANOVAs. Asterisks indicate that the value significantly differs from the control $(O O-O O)$. ${ }^{*} P<0.10, * * P<0.05$, $* * * P<0.01$. Post hoc tests were not performed on nutrient concentrations of plants that grew in the water compartment, due to the low number of replicates

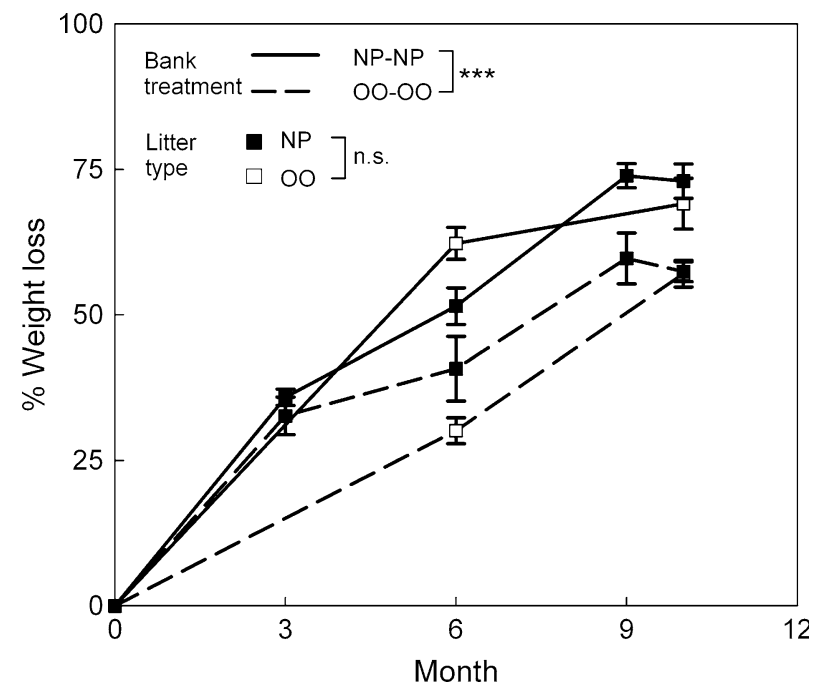

Figure 5. Weight loss through decomposition for the different types of Glyceria litter in the different treatments $( \pm \mathrm{SE})$. Litter harvested from banks without fertilization (open symbols) and litter harvested from banks with 3 years NP addition (closed symbols) was placed in the NP$\mathrm{NP}$ (solid lines) and OO-OO (dashed lines) treatments. ${ }^{*} P<0.10,{ }^{* *} P<0.05, * * * P<0.01$.

is much shorter in height than the eutrophic species, invaded and dominated the water compartment rapidly after the first year, Glyceria increased more strongly over the later years, suggesting that eventually, Menyanthes would be outcompeted in the water too. We therefore speculate that these mechanisms would eventually result in a decrease in plant diversity of floating mats in the field as eutrophication continues over much longer periods there. Besides, the dominating eutrophic shoreline species such as Glyceria and Juncus invade the water less frequently, or not at all, by floating on the water surface (Weeda and others 1999). Instead, these eutrophic species more often colonize surface water with rhizomes rooting in the bottom. Because this process will usually stop at a certain water depth due to wave action (Riis and Hawes 2003; Azza and others 2006), light limitation (Boedeltje and others 2001), or herbivory (Perrow and others 1997; E. S. Bakker unpublished), the formation of floating mats becomes less likely and the water body will remain open.

The poor performance of the aquatic species in the NP-NP and OO-NP treatments may also relate to competition. There, the emergent macrophytes growing from the bank filled the water compartment almost completely, outcompeting the aquatic species.

\section{Effects on Litter Accumulation}

Decomposition rates in Glyceria were comparable to those in other studies on Glyceria (B. P. Van de Riet unpublished) and our finding that decomposition was mainly determined by site conditions is in line with several other reciprocal litter experiments 
(Rejmánková and Houdková 2006; Moore and others 2007). On the community level, decomposition and litter accumulation would also depend on species composition, as species differ in litter production and decomposition rates (Graf and Rochefort 2009; B. P. Van de Riet unpublished). Like many herbs, the mesotropic species produced less litter and are therefore likely decomposed faster compared to grasses. Given that Glyceria increased dominance after fertilization, overall litter accumulation in fen shorelines might even be more contrasting when assessed for a whole plant community.

In the succession from open water floating fen, carr, or brown-moss fen (Van Wirdum and others 1992), accumulation rates of organic material are highest in the floating mat phase $\left(1 \mathrm{~kg} \mathrm{~m}^{-2} \mathrm{y}^{-1}\right.$; Bakker and others 1997). Results from the same study suggested that the litter accumulation rates of the different phases control their "turnover time" (that is, time needed for transition from one phase to the next; Bakker and others 1997). Therefore, the expanding floating mats represent the shortest phase in the complete succession from open water to alder forest. This implies that eutrophication would accelerate succession also indirectly, by increasing litter accumulation. Huotari and others (2007) found litter accumulation to play a comparable role in the succession of cut-over peat bogs. In wetlands, litter quantity and quality have been shown to strongly affect other processes like germination (Wilby and Brown 2001; Xiong and Nilsson 1999), establishment (Van der Putten and others 1997), and hydrology (Van Wirdum and others 1992), which might induce such a vegetation change toward later succession phases (Van der Putten and others 1997). In strongly eutrophic situations, however, more eutrophic species might be favored and the later succession phases, as argued before, might not be desirable (Van Wirdum and others 1992; Verhoeven and Bobbink 2001).

\section{Broader Perspective}

With this research, we showed that nutrient additions to both surface water and bank will change the functioning of riparian ecosystems in fens. Nutrient addition (mainly P) resulted in increased growth and cover of the water compartment. Plants had larger colonization distances on the bank as well as in the water, but only eutrophic species increased shoot density after nutrient addition. This may have caused their increased dominance on enriched banks. Nutrient addition further resulted in higher litter production and stimulated decom- 
position. Litter accumulation was calculated to be highest on banks with NP addition. Together, these processes imply that eutrophication would accelerate succession. Compared to the very oligotrophic control treatment in our mesocosm experiment, this turned out to be positive, increasing the colonization and plant diversity of the water compartment. However, in a more mesotrophic field situation where eutrophication continues over prolonged periods, it is not very likely that increased nutrient availability would result in the species-rich vegetation type aimed for by nature managers and policy makers (Van Wirdum and others 1992; Verhoeven and Bobbink 2001). First, given the more or less parabolic relationship between nutrient richness and biodiversity, strong eutrophication often results in vegetation with a lower biodiversity (Grime 1977). Second, the eutrophic species that increase dominance are less capable of the formation of mats (Weeda and others 1999). Third, as the mesocosm experiment clearly showed that succession accelerates, the short life span of the existing mats might decrease even further. In fact, Bakker and others (1994) calculated that the life span of the semi-aquatic phase decreased between 1937 and 1989 during which time nutrient inputs into the fen have increased drastically. To increase the probability of the formation of species-rich floating mats, restoration and management activities should therefore aim at reducing the nutrient concentrations in both water and bank. Careful monitoring of such management activities and field experiments could successively reveal how the mechanisms observed in our study interact in more complex situations.

\section{ACKNOWLEDGEMENTS}

This study was conducted within the National Research Programme "Ontwikkeling + Beheer Natuurkwaliteit," funded by the Dutch Ministry of Agriculture, Nature and Food Quality. We especially thank B. Willers for his daily care of the mesocosms and thank many other colleagues and students for assisting with the practical work and analyses. D. Whigham is acknowledged for editing the English.

\section{OPEN ACCESS}

This article is distributed under the terms of the Creative Commons Attribution Noncommercial License which permits any noncommercial use, distribution, and reproduction in any medium, provided the original author(s) and source are credited.

\section{REFERENCES}

Azza N, Denny P, Van de Koppel J, Kansiime F. 2006. Floating mats: their occurrence and influence on shoreline distribution of emergent vegetation. Freshw Biol 51:1286-97.

Bakker SA, Van den Berg NJ, Speleers BP. 1994. Vegetation transitions of floating wetlands in a complex of turbaries between 1937 and 1989 as determined from aerial photographs with GIS. Vegetatio 114:161-7.

Bakker SA, Jasperse C, Verhoeven JTA. 1997. Accumulation rates of organic matter associated with different successional stages from open water to carr forest in former turbaries. Plant Ecol 129:113-20.

Banach AM, Banach K, Peters RCJH, Jansen RHM, Visser EJW, Stępniewska Z, Roelofs JGM, Lamers LPM. 2009. Effects of long-term flooding on biogeochemistry and vegetation development in floodplains; a mesocosm experiment to study interacting effects of land use and water quality. Biogeosciences 6:1325-39.

Begon M, Harper JL, Townsend CR. 1996. Ecology: individuals, populations and communities. 3rd edn. Oxford: Blackwell Scientific. Chapter 17

Beltman B, Weijs WA, Sarneel JM. 2008. Werken de KRW-en Natura 2000-criteria voor sloten en veenplassen? H2O 8:25-7.

Boedeltje G, Smolders AJP, Roelofs JGM, Van Groenendael JM. 2001. Constructed shallow zones along navigation canals: vegetation establishment and change in relation to environmental characteristics. Aquat Conserv Mar Freshw Ecosyst 11:453-71.

Bremner JM, Mulvaney CS. 1982. Salicylic acid-thiosulphate modification of Kjeldahl method to include nitrate and nitrite. In: Page AC, Miller RH, Keeney DR, Eds. Methods of soil analysis. Part 2. Chemical and microbiological properties. Agronomy 9. Madison: Soil Science Society of America. pp. 621-2.

Geurts JJM, Sarneel JM, Willers BJC, Roelofs JGM, Verhoeven JTA, Lamers LPM. 2009. Interacting effects of sulphate pollution, sulphide toxicity and eutrophication on vegetation development in fens: a mesocosm experiment. Environ Pollut 157:2072-81.

Graf M, Rochefort L. 2009. Examining the peat-accumulating potential of fen vegetation in the context of fen restoration of harvested peatlands. Ecoscience 16:158-66.

Grasshoff K, Johannsen H. 1972. A new sensitive and direct method for the automatic determination of ammonia in sea water. J Cons Perm Int Explor Mer 34:516-21.

Grime JP. 1977. Evidence for the existence of three primary strategies in plants and its relevance to ecological and evolutionary theory. Am Nat 111:1169-94.

Grimm NB, Gergel SE, McDowell WH, Boyer EW, Dent CL, Groffman P, Hart SC, Harvey J, Johnston C, Mayorga E, McClain ME, Pinay G. 2003. Merging aquatic and terrestrial perspectives of nutrient biogeochemistry. Oecologia 137:485-501.

Hodge A. 2004. The plastic plant: root responses to heterogeneous supplies of nutrients. New Phytol 162:9-24.

Hultine KR, Jackson TL, Burtch KG, Schaeffer SM, Ehleringer JR. 2008. Elevated stream inorganic nitrogen impacts on a dominant riparian tree species: results from an experimental riparian stream system. J Geophys Res 113(G4): G04025.

Huotari N, Tillman-Sutela E, Kauppi A, Kubin E. 2007. Fertilization ensures rapid formation of ground vegetation on cutaway peatlands. Can J For Res 37:874-83. 
Kamphake LJ, Hannah SA, Cohen JM. 1967. Automated analysis for nitrate by hydrazine reduction. Water Res 1:205-6.

Knops JMH, Bradley KL, Wedin DA. 2002. Mechanisms of plant species impacts on ecosystem nitrogen cycling. Ecol Lett 5:454-66.

Lamers LPM, Smolders AJP, Roelofs JGM. 2002. The restoration of fens in the Netherlands. Hydrobiologia 478:107-30.

Lamers LPM, Geurts JM, Bontes B, Sarneel JM, Pijnappel H, Boonstra H, Schouwenaars J, Klinge M, Verhoeven JTA, Ibelings BW, Van Donk E, Verberk WCEP, Kuijper B, Esselink H, Roelofs JGM. 2006. Onderzoek ten behoeve van het herstel en beheer van Nederlandse laagveenwateren; Eindrapportage 2003-2006 (Fase 1). Ede, LNV-DK. pp. 33-60.

Macek P, Rejmánková E. 2007. Response of emergent macrophytes to experimental nutrient and salinity additions. Funct Ecol 21:478-88.

Moore TR, Bubier JL, Bledzki L. 2007. Litter decomposition in temperate peatland ecosystems: the effect of substrate and site. Ecosystems 10(6): 949-63.

Nilsson C, Svedmark M. 2002. Basic principles and ecological consequences of changing water regimes: riparian plant communities. Environ Manag 30:468-80

Perrow MRJ, Schutten H, Howes JR, Holzer T, Madgwick FJ, Jowitt AJD. 1997. Interactions between coot (Fulica atra) and submerged macrophytes: the role of birds in the restoration process. Hydrobiologia 342-343:241-55.

Portielje R, Roijackers RM. 1995. Primary succession of aquatic macrophytes in experimental ditches in relation to nutrient input. Aquat Bot 50:127-40.

Rejmánková E, Houdková K. 2006. Wetland plant decomposition under different nutrient conditions: what is more important, litter quality or site quality? Biogeochemistry $80: 245-62$.

Renöfält BM, Nilsson C, Jansson R. 2005. Spatial and temporal patterns of species richness in a riparian landscape. J Biogeogr $32: 2025-37$

Riis T, Hawes I. 2003. Effect of wave exposure on vegetation abundance, richness and depth distribution of shallow water plants in a New Zealand lake. Freshw Biol 48:75-87.

Robinson D. 1994. Tansley review No. 73. The responses of plants to non-uniform supplies of nutrients. New Phytol 127:635-74.

Saunders DL, Kalff J. 2001. Nitrogen retention in wetlands, lakes and rivers. Hydrobiologia 443:205-12.
Schade JD, Marti E, Welter JR, Fisher SG, Grimm NB. 2002. Sources of nitrogen to the riparian zone of a desert stream: implications for riparian vegetation and nitrogen retention. Ecosystems 5:68-79.

Schade JD, Welter JR, Marti E, Grimm NB. 2005. Hydrologic exchange and $\mathrm{N}$ uptake by riparian vegetation in an arid-land stream. J N Am Benthol Soc 24:19-28.

Schils R, Snijders P. 2004. The combined effect of fertilizer nitrogen and phosphorus on herbage yield and changes in soil nutrients of a grass/clover and grass-only sward. Nutr Cycl Agroecosyst 68:165-79.

Shaver GR, Melillo JM. 1984. Nutrient budgets of marsh plants: efficiency concepts and relation to availability. Ecology 65:1491-510.

Smith RL, Smith TM. 1998. Elements of ecology. 4th edn. San Francisco: Benjamin-Cummings.

Van Belle J, Barendregt A, Schot PP, Wassen MJ. 2006. The effects of groundwater discharge, mowing and eutrophication on fen vegetation evaluated over half a century. Appl Veg Sci 9:195-204.

Van der Putten WH, Peters BAM, Van den Berg MS. 1997. Effects of litter on substrate conditions and growth of emergent macrophytes. New Phytol 135:527-37.

Van Wirdum G, Den Held AJ, Schmitz M. 1992. Terrestrializing fen vegetation in former turbaries in the Netherlands. In: Verhoeve JTA, Ed. Fens and bogs in the Netherlands. Dordrecht: Kluwer. pp. 323-60.

Verhoeven JTA, Bobbink R. 2001. Plant diversity of fen landscapes in the Netherlands. In: Gopal B, Junk WJ, Davis JA, Eds. Biodiversity in wetlands: assessment, function and conservation. Leiden: Backhuys Publishers.

Vitousek P. 1982. Nutrient cycling and nutrient use efficiency. Am Nat 119:553-72.

Ward JV, Tockner K, Arscott DB, Claret C. 2002. Riverine landscape diversity. Freshw Biol 47:517-39.

Weeda E, Westra R, Westra C, Westra T. 1999. Nederlandse Oecologische Flora met als ondertitel Wilde planten en hun relaties. Zeist: KNNV Publishing.

Wilby A, Brown VK. 2001. Herbivory, litter and soil disturbance as determinants of vegetation dynamics during early old-field succession under set-aside. Oecologia 127:259-65.

Xiong SJ, Nilsson C. 1999. The effects of plant litter on vegetation: a meta-analysis. J Ecol 87:984-94. 